\title{
STRATEGI PENGEMBANGAN BUDIDAYA LELE DUMBO Clarias sp. MELALUI PROGRAM PENGEMBANGAN USAHA MINA PEDESAAN PERIKANAN BUDIDAYA DI KABUPATEN BULELENG (Aquaculture Development of Catfish Clarias sp. through Fisheries Business Development in Village on Fish Aquaculture Program Implementation in Buleleng Regency)
}

\author{
I Ketut Wija Negara*, Marsoedi dan Edi Susilo \\ Program Pascasarjana, Fakultas Perikanan dan Ilmu Kelautan, Universitas Brawijaya, \\ Jalan Veteran, Malang, 65145. \\ *Penulis korespondensi. Tel: 081239325757. Email: wijanegara@gmail.com.
}

Diterima: 18 Juni 2015

Disetujui: 7 September 2015

\begin{abstract}
Abstrak
Permintaan produksi lele dumbo yang tinggi di Provinsi Bali belum mampu dimaksimalkan peluangnya oleh para Kelompok Pembudidaya Ikan (Pokdakan) penerima bantuan langsung masyarakat melalui program Pengembangan Usaha Mina Pedesaan Perikanan Budidaya (PUMP PB) tahun 2011 - 2013 di Kabupaten Buleleng. Faktornya adalah jumlah penyuluh perikanan yang mendampingi pelaksanaan kegiatan tersebut, kemampuan Pokdakan pada bidang budidaya, terbatasnya informasi teknik budidaya, kontinunitas ketersediaan benih yang berkualitas di Kabupaten Buleleng. Hasil evaluasi dan tidakan melalui Participatory Action Research (PAR) adalah memanfaatkan faktor lingkungan eksternal melalui pemanfaatan aliran irigasi subak untuk budidaya pembesaran lele dumbo, pemberian pellet fermentasi mendapatkan perbandingan Feed Convertion Ratio (FCR) 0,997 : 1,0. Hasil matrik IFAS dan EFAS, dari penelitian ini didapatkan jumlah $\mathrm{x}=0,296$ dan $\mathrm{y}=0,058$ yang menunjukan strategi progresif yang menandakan sebuah organisasi yang kuat dan berpeluang. Salah satu strategi yang dapat dilakukan adalah dengan memanfaatkan lingkungan perairan dari aliran irigasi untuk kegiatan usaha budidaya pembesaran lele dumbo di Kabupaten Buleleng sehingga dapat memenuhi tingginya permintaan lele dumbo di Provinsi Bali.
\end{abstract}

Kata kunci:. budidaya, Clarias sp, pengembangan, perairan, SWOT.

\begin{abstract}
The high demand of catfish production in Bali province has not been able to be made use by local fish cultivation groups (Pokdakan) which are recipients of Fisheries Business Development in Village on Fish Aquaculture Program (PUMP PB) 2011 - 2013 Buleleng regency. The contributing factors are the number of the attending fishery counselors in the program implementation, the ability of Pokdakans on aquacultural field, the limited information on aquaculture techniques and the continuity of high quality seed availability in Buleleng regency. Evaluation and treatment result of Participatory Action Research (PAR) is that subak irrigation system can be used for the catfish rearing aquaculture, fermented feed utilization showed Feed Conversion Ratio (FCR) 0.997 : 1.0. Based on IFAS and EFAS matrices analysis, achieved $\mathrm{x}$ value $=0.296$ and $\mathrm{y}=0.058$ showed progressive strategy which means a strong and opportune organization. One strategy is utilization of subak irrigation system for catfish rearing aquaculture in Buleleng regency to meet the high demand of the catfish in Bali province.
\end{abstract}

Keywords: aquaculture, aquatic, Clarias sp, cultivation, SWOT.

\section{PENDAHULUAN}

Pertumbuhan produksi budidaya air tawar meningkat cukup signifikan dalam kurun waktu lima tahun terakhir yaitu sebesar 8,83\%. Pertumbuhan jenis budidaya tertinggi terjadi pada budidaya kolam, yaitu sebesar $17,82 \%$. Salah satu komoditas dengan penggunaan media kolam adalah komoditas lele dumbo (Anonim, 2013). Perkembangan usaha budidaya ikan lele semakin meningkat setelah masuknya jenis lele dumbo (Clarias sp.) ke Indonesia (Khairuman dan Amri,
2002). Faktor yang menjadi pesatnya perkembangan budidaya lele dumbo karena dalam proses produksinya lebih banyak memanfaatkan sumber daya yang ada dan menggunakan komponen lokal yang cukup besar, sementara hasil usaha budidaya Lele sangat berpotensi besar terhadap pasar domestik (Tajerin, 2008).

Menurut Jaja dkk. (2013), pesatnya perkembangan lele dumbo di Indonesia karena memiliki rasa yang enak, harga yang cukup terjangkau, terdapat kandungan gizi yang tinggi, pertumbuhan ikan relatif cepat dan mudah 
berkembang biak. Menurut Purwono dkk., (2011), protein yang terdapat dalam Lele merupakan protein yang amat penting dan istimewa, karena bukan hanya berfungsi sebagai penambah jumlah protein konsumsi tetapi juga sebagai pelengkap mutu protein dalam pola makan. Peningkatan jumlah produksi lele dumbo terjadi karena ikan ini dapat dibudidayakan pada lahan dan sumber air yang terbatas, dengan padat tebar yang tinggi, menyukai semua jenis pakan, modal usahanya relatif rendah karena dapat menggunakan sumber daya yang ada, teknologi mudah dikuasai oleh masyarakat dan pemasaran ukuran konsumsinya pun relatif mudah (Ferdian dkk., 2012).

Potensi penyerapan hasil produksi lele dumbo konsumsi di Provinsi Bali sangat menjanjikan, kebutuhan hasil produksi tersebut masih belum dapat dipenuhi oleh beberapa Kabupaten di wilayahnya. Peluang yang besar tersebut berusaha dimanfaatkan oleh Kabupaten Buleleng sebagai daerah dengan terluas di Provinsi Bali yaitu 136.588 hektar atau 24,25\% dari luas Propinsi Bali melalui kebijakan pemerintah Program Pengembangan Usaha Mina Pedesaan Perikanan Budidaya (PUMP PB). Produksi lele di Provinsi Bali rata-rata disumbangkan oleh beberapa kabupaten di daerahnya, yaitu Kabupaten Tabanan, Bangli, Buleleng, dan Klungkung, sementara sisa dari kebutuhan lele di Provinsi Bali dipenuhi oleh pasokan dari luar daerah, seperti daerah Jember, Banyuwangi dan Situbondo (Sudana dkk., 2013).

Penelitian ini mencoba merumuskan beberapa permasalahan yang ada seperti evaluasi produksi yang dihasilkan oleh Pokdakan lele dumbo penerima BLM PUMP PB tahun 2011-2013 dan teknologi budidaya yang digunakan oleh para kelompok pembudidaya yang menerima BLM PUMP PB tahun 2011 sampai dengan tahun 2013. Permasalahan lain berupa evaluasi potensi lingkungan yang mampu mendukung keberhasilan kegiatan budidaya pembesaran lele dumbo dan strategi pengembangan budidaya lele dumbo yang tepat di Kabupaten Buleleng.

Penelitian ini bertujuan untuk mengevaluasi kegiatan budidaya perikanan yang dilakukan oleh Kelompok Pembudidaya Ikan (Pokdakan) penerima PUMP PB tahun 2011 sampai dengan 2013 di Kabupaten Buleleng dan memanfaatkan lingkungan perairan aliran irigasi dengan inovasi teknologi budidaya yang tepat. Tujuan lain adalah untuk dapat memberikan gambaran investasi usaha budidaya lele Dumbo dengan inovasi teknologi budidaya yang sederhana serta dapat menyampaikan strategi pengembangan budidaya lele dumbo kepada Pemerintah Daerah di
Kabupaten Buleleng melalui pemanfaatan PUMP PB

\section{METODE PENELITIAN}

\section{Waktu dan Lokasi}

Tahapan penelitian ini diawali dengan mengajukan surat perijinan di Dinas Kelautan dan Perikanan (DISKANLA) Kabupaten Buleleng mulai dari bulan September sampai dengan bulan Desember 2013, hal ini dilakukan agar kegiatan wawancara terhadap Pokdakan penerima PUMP PB. Waktu penelitian percobaan pembesaran lele dumbo dilaksanakan dari tanggal 7 Januari 2014 sampai dengan 30 Juni 2014 di Desa Sambangan Kecamatan Sukasada Kabupaten Buleleng.

\section{Prosedur}

Data primer didapatkan melalui wawancara dengan responden terdiri dari semua pokdakan lele penerima BLM PUMP tahun 2011 sampai dengan 2013 sebanyak 14 Pokdakan terdiri atas Ketua, Sekretaris dan Bendahara di setiap pokdakan tersebut. Jumlah responden sebanyak 42 orang, $n \geq$ 30 dianggap sudah terdistribusi mendekati normal, pengamatan langsung melalui evaluasi pokdakan lele penerima PUMP PB yang masih aktif melakukan kegiatan budidaya, berinteraksi langsung dengan staf bidang budidaya di Dinas Perikanan dan Kelautan (DISKANLA) Kabupaten Buleleng. Data sekunder dikumpulkan melalui dokumen dan arsip dari DISKANLA Kabupaten Buleleng.

Menurut Jorgensen (1989) Participation Action Research (PAR) dapat dilakukan dengan percobaan yaitu dengan melakukan pembesaran budidaya lele dumbo dari hasil analisa dan wawancara terhadap pokdakan lele. Pengadaan benih dari luar daerah yaitu dari Kabupaten Bayuwangi, hal ini karena tidak tersedianya benih lele dumbo di Kabupaten Buleleng. Jenis kolam yang digunakan adalah dengan kolam terpal, dengan total jumlah tiga kolam, terdiri ada dua kolam berukuran $2 \times 3 \times 1 \mathrm{~m}$ dan satu kolam berukuran $5 \times 4 \times 1 \mathrm{~m}$ dan total jumlah benih ditebar adalah 6.500 ekor dengan ukuran rata-rata 5 cm. Menurut Hermawan dkk. (2012) padat tebar sangat berpengaruh terhadap pakan, karena bahan buangan metabolik akan juga menganggu laju pertumbuhan, konsentrasi, dan kelulus hidupan. Padat tebar 100 ekor $/ \mathrm{m}^{2}$ tidak berpengaruh pada laju pertumbuhan, karna pada padat tebar ini lele dumbo dapat menyesuaikan pakan dengan baik.

Pakan diberikan dua kali sehari, dimana pakan yang diberikan adalah pakan pelet komersil PF dan 781-1, 781-2, 781-3. Pakan pelet terlebih dahulu 
difermentasi selama 24 jam dengan campuran 100 $\mathrm{mL}$ probiofish, $300 \mathrm{~mL}$ molase, $1 \mathrm{~L}$ air dan 1500 pakan pellet, sebelum diberikan ke lele.

Tahapan analisis SWOT dimulai dengan mengidentifikasi Internal Strategic Faktors Analiysis Summary (IFAS) dan External Strategic Faktors Analysis Summary (EFAS) yang ada di dalam kegiatan budidaya Lele dumbo di Kabupaten Buleleng. Tahap berikutnya adalah menggambarkan faktor internal dan faktor eksternal untuk menghasilkan empat golongan strategi alternatif melalui matrik SWOT. Setelah itu dilanjutkan dengan menginventarisir angka-angka yang dihasilkan dari identifikasi pembobotan faktor internal dan faktor eksternal ke dalam matrik IFAS dan EFAS. Data SWOT kualitatif dikembangkan secara kuantitatif melalui perhitungan analisa SWOT.

\section{HASIL DAN PEMBAHASAN}

Pelaksanaan Program PUMP PB Tahun 2011 sampai dengan Tahun 2013 di Kabupaten Buleleng adalah berjumlah total 25 Pokdakan, 14 kelompok tersebut membudidayakan lele (Tabel 1).
Pokdakan yang membudidayakan lele pada tahun 2011 sebanyak lima pokdakan yang ditetapkan, pada tahun 2011 pembudidaya lele di Kabupaten Buleleng masih sangat terbatas. Hal ini disebabkan karena kegiatan usaha budidaya ikan air tawar masih tidak popular di Kabupaten Buleleng, kecuali masyarakat pada daerah sekitar Danau Buyan dan Tamblingan. Kelompok yang membudidayakan lele dumbo pada Tahun 2012 sebanyak tiga Pokdakan dari total enam pokdakan yang ditetapkan menerima bantuan. Berkurangnya penerima BLM dari pokdakan lele disebabkan karena hasil produksi dengan biaya produksi kurang seimbang, sehingga dalam penilaian yang dilakukan oleh penyuluh perikanan di Kabupaten Buleleng mencoba alternatif budidaya air tawar komoditas lainnya. Tahun 2013 kelompok yang membudidayakan lele dumbo sebanyak enam kelompok dari total jumlah 14 Pokdakan yang ditetapkan menerima bantuan tersebut.

Berikut disajikan produksi dan pendapatan Pokdakan PUMP PB 2011 - 2013 yang membudidayakan lele di Kabupaten Buleleng. Tahun 2011 total jumlah hasil produksi lele sebanyak $27.160 \mathrm{~kg}$ dengan total jumlah hasil pendapatan sebesar Rp 296.672.500, Tahun 2012

Tabel 1. Pokdakan BLM PUPM PB Tahun $2011-2013$.

\begin{tabular}{|c|c|c|c|}
\hline Nama kelompok & Komoditas & Jumlah anggota (orang) & Kecamatan \\
\hline \multicolumn{4}{|c|}{ Tahun 2012 dengan nilai BLM Rp. 100.000 .000} \\
\hline Sangkuriang & Lele & 26 & Gerokgak \\
\hline Banyu Tawar & Lele & 16 & Gerokgak \\
\hline Mekar Sari & Lele & 12 & Busungbiu \\
\hline Santi Loka & Lele & 20 & Buleleng \\
\hline Mina Sari & Lele & 14 & Kubutambahan \\
\hline \multicolumn{4}{|c|}{ Tahun 2012 dengan nilai BLM Rp. 65.000 .000} \\
\hline Ulam Sari & Lele & 16 & Busungbiu \\
\hline Mina Duta Bahari & Lele & 10 & Sawan \\
\hline Ayu Kinardi & Lele & 15 & Kubutambahan \\
\hline Mina Sejahtera & Gurame & 14 & Busungbiu \\
\hline Toya Mantra & Nila & 16 & Busungbiu \\
\hline Dharma Murti & Nila & 11 & Busungbiu \\
\hline \multicolumn{4}{|c|}{ Tahun 2013 dengan nilai BLM Rp. 65.000 .000} \\
\hline Dharma Karya & Lele & 19 & Busungbiu \\
\hline Sekar Sari & Lele & 13 & Buleleng \\
\hline Mina Sejahtera & Lele & 20 & Sukasada \\
\hline Mina Kemuning Swandiri & Lele & 14 & Kubutambahan \\
\hline Mina Mukti Swadiri & Lele & 12 & Kubutambahan \\
\hline Sari Ulam & Lele & 19 & Kubutambahan \\
\hline Werdi Asri & Nila & 17 & Kubutambahan \\
\hline Telaga Maju & Nila & 12 & Sukasada \\
\hline Mina Sejahtera & Nila & 12 & Sawan \\
\hline Mina Barramundi & Kakap Putih & 16 & Gerokgak \\
\hline Dharma Kerti & Nila & 16 & Busungbiu \\
\hline Amerta Sari & Nila & 18 & Busungbiu \\
\hline Tunas Harapan & Nila & 14 & Seririt \\
\hline Bakti Pertiwi & Nila & 13 & Seririt \\
\hline
\end{tabular}

Sumber : Anonim, 2014 
sebanyak 9.248,5 $\mathrm{kg}$ dengan jumlah hasil pendapatan sebesar Rp 104.972.000 dan Tahun 2013 sebanyak $615 \mathrm{~kg}$ dengan jumlah hasil pendapatan sebesar Rp 8.980.000 (Anonim, 2014 ).

Peranan alami kualitas air sangat mempengaruhi seluruh komunitas dalam perairan (bakteri, tanaman, ikan, dan zooplankton). Limbah dari budidaya lele dumbo sangat cepat berdampak pada penurunan kualitas airnya, sehingga pada saat membudidayakan lele baik secara semi intensif maupun intensif pengelolaan kualitas air sangat penting untuk terus dilakukan (Septiani dkk, 2014). Pemanfaatan sumber daya perairan aliran irigasi untuk melakukan budidaya pembesaran lele dumbo yang dilakukan di Desa Sambangan Kecamatan Sukasada Kabupaten Buleleng mendapatkan uji parameter kualitas air. Menurut SNI (Anonim, 2002), kualitas air untuk budidaya pembesaran lele adalah suhu optimal berkisar antara $25-30{ }^{\circ} \mathrm{C}$, oksigen terlarut (DO) tidak kurang dari $4 \mathrm{mg} / \mathrm{L}$ dan pH nya adalah 6,5-9.0 (Anonim, 2002). Berikut adalah kualitas air pada aliran irigasi subak Desa Sambangan (Tabel 2).

Pemberian pakan yang sudah difermentasi adalah setelah waktu pemberian pellet $P F 1000$ dan waktu pemberian makan yaitu pada pagi dan sore hari. Menurut Kirna dkk. (2013) melakukan fermentasi pelet untuk meningkatkan nilai nutrisi pada pakan. Hasil analisis uji proksimat pada fermentasi pelet jenis 781-2 menghasilkan kandungan zat pakan yang ditampilkan pada Tabel 3.

Total pakan fermentasi yang dihabiskan dalam proses budidaya pembesaran Lele Dumbo yang dilakukan selama 120 hari adalah $350 \mathrm{~kg}$, dengan menghasilkan total jumlah produksi sebesar $351 \mathrm{~kg}$. Perbandingan konsumsi pakan untuk menghasilkan daging (FCR) pada proses pembesaran lele dumbo penelitian ini adalah $0,997: 1,0$ (Tabel 4 dan Tabel 5).

Proses budidaya pembesaran lele dumbo ini menggunakan sistem pengelolaan air dengan cara mensirkulasi air ke dalam kolam dari sumber aliran irigasi subak. Hal ini dilakukan untuk mengurangi pencemaran lingkungan udara, karena bau yang ditimbulkan dari proses budidaya pembesaran lele dumbo ini sangat menyengat, menjaga nafsu makan lele dumbo, dan memperbaiki kualitas air pada kolam tersebut.

Menurut Mahyuddin dkk. (2014), panen dilakukan saat ukuran lele dumbo sudah 8-10 ekor $/ \mathrm{kg}$, dengan harga rata-rata per kilogramnya adalah Rp 15.000-16.000. Total hasil produksi yang didapatkan adalah sebesar $351 \mathrm{~kg}$ dengan rata-rata ukuruan lele dumbo 10 ekor $/ \mathrm{kg}$. Pemasaran hasil panen kegiatan budidaya ini dipasarkan kepada pengepul, usaha pemancingan dan cara menawarkan kepada para pengepul atau kepada pembudiaya lainnya untuk membeli keseluruhan

Tabel 2. Parameter kualitas air aliran irigasi Subak.

\begin{tabular}{lr}
\hline \multicolumn{1}{c}{ Parameter kualitas air } & \multicolumn{1}{c}{ Hasil } \\
\hline Suhu & $27^{\circ} \mathrm{C}$ \\
Oksigen terlarut (DO) & $6 \mathrm{mg} \mathrm{O} / \mathrm{L}$ \\
Kecerahan & $10 \mathrm{~cm}$ \\
$\mathrm{pH}$ & 7,16 \\
\hline
\end{tabular}

Sumber : Balai Karantina Ikan Pengendalian Mutu dan Keamanan Hasil Perikanan Kelas I Denpasar.

Tabel 3. Uji proksimat pelet fermentasi 781-2.

\begin{tabular}{lllll}
\hline Bahan kering (\%) & Abu* $(\%)^{*}$ & Protein kasar* $(\%)$ & Serat kasar* $(\%)$ & Lemak kasar $(\%)$ \\
\hline 54,13 & 9,54 & 34,25 & 4,83 & 5,49 \\
\hline
\end{tabular}

Tabel 4. Lama waktu pembesaran dan jumlah konsumsi pakan.

\begin{tabular}{cccc}
\hline Jenis pakan & Jumlah pakan $(\mathrm{kg})$ & Harga $(\mathrm{Rp} / \mathrm{kg})$ & Jangka waktu $(\mathrm{Tggl} / \mathrm{Bln} / \mathrm{Thn})$ \\
\hline PF 1000 & 10 & 15.000 & $(01 / 03 / 14-20 / 03 / 14)$ \\
$781-1$ & 30 & 15.000 & $(21 / 03 / 14-22 / 04 / 14)$ \\
$781-2$ & 160 & 9.500 & $(23 / 04 / 14-08 / 06 / 14)$ \\
$781-3$ & 150 & 9.500 & $(09 / 06 / 14-30 / 06 / 14)$ \\
Total & 350 & & 120 hari \\
\hline
\end{tabular}

Sumber: Data primer, 2014.

Tabel 5. Hasil produksi dan hasil pendapatan.

\begin{tabular}{cccrrc}
\hline Waktu & Rata-rata bobot (ekor/Kg) & Jumlah $(\mathrm{kg})$ & Harga $(\mathrm{Rp})$ & Jumlah $(\mathrm{Rp})$ & Keterangan \\
\hline $07 / 06 / 14$ & 10 & 20 & 16.000 & 320.000 & Pemancingan \\
$10 / 06 / 14$ & 10 & 41 & 15.500 & 635.500 & Pengepul \\
$24 / 06 / 14$ & 10 & 15 & 16.000 & 240.000 & Pemancingan \\
$27 / 06 / 14$ & 10 & 30 & 16.000 & 480.000 & Pemancingan \\
$29 / 06 / 14$ & 10 & 95 & 16.500 & 1.567 .500 & Pengepul \\
$30 / 06 / 14$ & $10-15$ & 150 & 12.500 & 1.875 .000 & Pembudidaya \\
Total & & 351 & & 5.118 .000 & \\
\hline
\end{tabular}

Sumber : Data primer, 2014. 
lele dumbo dalam kolam tanpa dilakukannya terlebih dahulu proses pernyortiran hasil panen yang biasanya dilakukan oleh beberapa pembudidaya di Kabupaten Buleleng.

\section{Strategi Pengembangan Budidaya Lele Dumbo}

Faktor strategis internal yang menjadi kekuatan utama adalah adanya program PUMP PB dengan nilai tertinggi sebesar 0,116 dan kelemahan paling utama dengan nilai tertinggi adalah keterbatasan tenaga penyuluh perikanan dalam melakukan pendampingan dengan nilai bobot sebesar 0,105 . Total bobot skor IFAS sebesar 2,838 dan selisih total IFAS adalah sebesar 0,276 (Tabel $6)$.

Faktor yang menjadi peluang utama adalah besarnya permintaan dan tingginya harga Lele Dumbo konsumsi di Kabupaten Buleleng dengan nilai bobot sebesar 0,112, sedangkan ancaman utama adalah ketidak percayaan (paradigma negatif) akibat kegagalan para pembudidaya sebelumnya, terdapat pepatah masyarakat pembudidaya "pelihara lele jual sapi" dengan nilai bobot sebesar 0,110. Total bobot skoring sebesar 2,639 dan selisih total bobot skoring sebesar 0,039 (Tabel 7).

Tabel 6. Analisis faktor internal dari Pokdakan PUMP PB dan DISKANLA.

\begin{tabular}{|c|c|c|c|c|}
\hline No & Aspek & Bobot & Nilai & Skor \\
\hline \multicolumn{5}{|c|}{ A. Faktor kekuatan (S) } \\
\hline 1. & Terdapat lahan yang potensial & 0,105 & 3 & 0,315 \\
\hline 2. & Dukungan dari pemerintah daerah & 0,105 & 3 & 0,315 \\
\hline 3. & Memiliki balai benih ikan air tawar (BBI Ringdikit) & 0,087 & 2 & 0,172 \\
\hline 4. & Program PUMP PB & 0,116 & 4 & 0,464 \\
\hline \multirow[t]{2}{*}{5.} & Jumlah pokdakan lele penerima PUMP PB $2011-2013$ & 0,097 & 3 & 0,291 \\
\hline & Jumlah faktor kekuatan & 0,510 & & 1,557 \\
\hline \multicolumn{5}{|c|}{ B. Faktor kelemahan (W) } \\
\hline 1. & Keterbatasan informasi teknologi budidaya Lele Dumbo & 0,095 & 2 & 0,190 \\
\hline 2. & Keterbatasan kemampuan SDM Pokdakan penerima BLM & 0,091 & 2 & 0,182 \\
\hline 3. & Keterbatasan tenaga penyuluh perikanan & 0,105 & 3 & 0,315 \\
\hline 4. & $\begin{array}{l}\text { BBI Ringdikit belum bisa memproduksi benih lele secara kontinunitas dan } \\
\text { berkualitas }\end{array}$ & 0,097 & 3 & 0,291 \\
\hline \multirow[t]{3}{*}{5.} & $\begin{array}{l}\text { Belum adanya penataan ruang pemanfaatan wilayah potensial untuk budidaya } \\
\text { lele }\end{array}$ & 0,101 & 3 & 0,303 \\
\hline & Jumlah faktor kelemahan & 0,490 & & 1,281 \\
\hline & Total faktor IFAS $(\mathrm{S}+\mathrm{W})$ & 1,000 & & 2,838 \\
\hline \multicolumn{4}{|c|}{ Selisih total skor kekuatan - total kelemahan $(S-W)=x$} & 0,276 \\
\hline
\end{tabular}

Tabel 7. Analisis faktor eksternal usaha budidaya lele dumbo.

\begin{tabular}{|c|c|c|c|c|}
\hline No & Aspek & Bobot & Nilai & Skor \\
\hline \multicolumn{5}{|c|}{ A. Faktor peluang $(\mathrm{O})$} \\
\hline 1. & Permintaan dan tingginya harga lele dumbo konsumsi di Kabupaten Buleleng & 0,112 & 3 & 0,336 \\
\hline 2. & Karakteristik lele dumbo & 0,097 & 2 & 0,194 \\
\hline 3. & Karakteristik masyarakat di Kabupaten Buleleng & 0,101 & 3 & 0,303 \\
\hline 4. & Budidaya lele dumbo meningkatkan peran sektor perikanan & 0,088 & 2 & 0,176 \\
\hline \multirow[t]{3}{*}{5.} & $\begin{array}{l}\text { Menciptakan usaha kemitraan seperti usaha pembenihan, pakan dan } \\
\text { pengolahan. }\end{array}$ & 0,110 & 3 & 0,330 \\
\hline & Jumlah faktor peluang & 0,509 & & 1,339 \\
\hline & \multicolumn{4}{|l|}{ B. Faktor ancaman (T) } \\
\hline 1. & $\begin{array}{l}\text { Paradigma negatif akibat kegagalan kegiatan usaha oleh pembudidaya ikan lele } \\
\text { sebelumnya. }\end{array}$ & 0,110 & 3 & 0,330 \\
\hline 2. & $\begin{array}{l}\text { Terbatasnya keberadaan distributor pellet pakan sehingga harga pellet semakin } \\
\text { mahal }\end{array}$ & 0,101 & 3 & 0,303 \\
\hline 3. & $\begin{array}{l}\text { Pokdakan penerima PUMP PB yang membudidayakan ikan lala belum mampu } \\
\text { meningkatkan hasil produksinya }\end{array}$ & 0,097 & 2 & 0,194 \\
\hline 4. & $\begin{array}{l}\text { Monopoli oleh para pengepul dalam menentukan harga dan banyaknya hasil } \\
\text { produksi yang masuk dari luar daerah }\end{array}$ & 0,088 & 2 & 0,176 \\
\hline 5. & Ketersediaan benih & 0,099 & 3 & 0,297 \\
\hline & Jumlah faktor ancaman & 0,490 & & 1,300 \\
\hline & Total faktor EFAS $(\mathrm{O}+\mathrm{T})$ & 0,999 & & 2,639 \\
\hline & Selisih total Skor peluang - total ancaman $=\mathrm{O}-\mathrm{T}=\mathrm{y}$ & & & 0,039 \\
\hline
\end{tabular}


Tabel 8. Matriks IFAS dan EFAS.

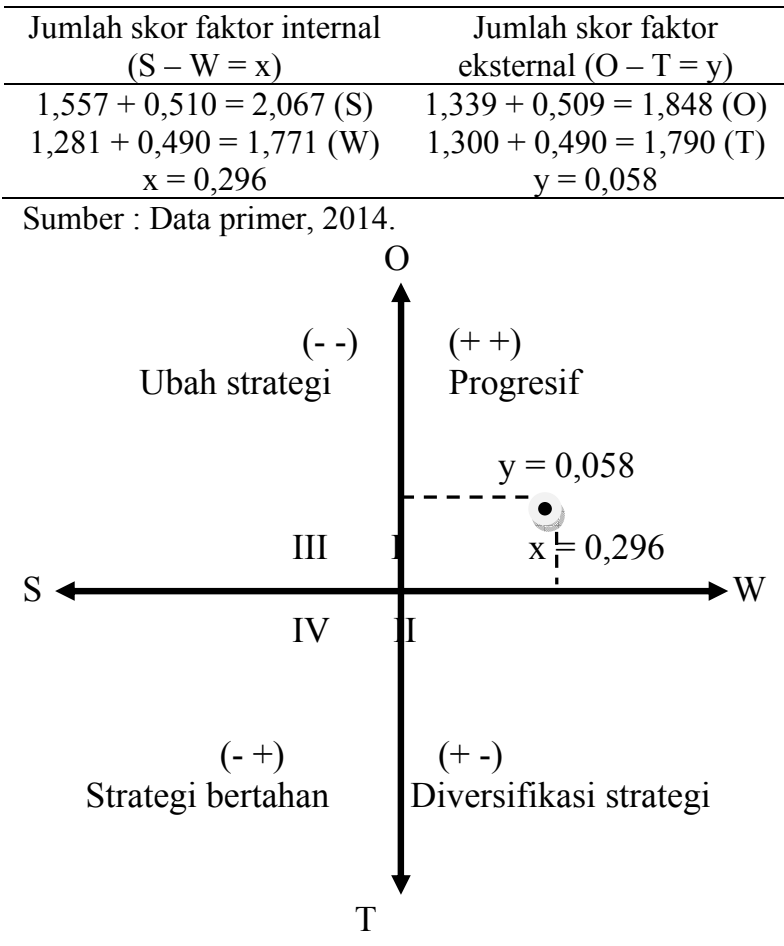

Gambar 1. Space Matrix SWOT (Rangkuti, 2004).

\section{Matrik SWOT}

Identifikasi IFAS dan EFAS menghasilkan empat golongan alternatif strategi yang kemudian dapat dilaksanakan. Dengan demikian alternatif strategi tersebut mampu meningkatkan peran penyuluh perikanan, selalu member pendampingan kepada Pokdakan lele agar dapat menghindari kegagalan usaha budidaya, sebagai alternatif usaha masyarakat dengan teknologi budidaya lele yang tepat dan BBI Ringdikit wajib memproduksi benih secara kontinu dan berkualitas. Berdasarkan hasil identifikasi faktor IFAS dan EFAS berupa angkaangka kemudian dinventarisasi kedalam Matriks IFAS dan EFAS (Tabel 8).

Fokus analisis dan skoring yaitu diperoleh sumbu $\mathrm{x}=0,296$ dan sumbu $\mathrm{y}=0,058$ kemudian hasil analisis dituangkan dalam gambar kuadran SWOT (Gambar 1). Posisi ini menandakan strategi progresif (kuadran i; positif, positif) dimana sebuah organisasi yang kuat dan berpeluang.

\section{KESIMPULAN}

Penggunaan kolam terpal dengan konstruksi yang tepat dapat memanfaatkan lahan yang terbatas. Pemanfaatan lingkungan perairan aliran irigasi subak efektif digunakan pada kegiatan budidaya pembesaran lele dumbo sehingga dapat memperbaiki kualitas air dan menghemat biaya sirkulasi air. Hasil pellet fermentasi yang dilakukan mendapatkan konversi pakan menjadi daging (FCR) $0,997: 1,0$ sehingga perlakuan ini sangat layak untuk digunakan oleh para pembudidaya lele dumbo di Kabupaten Buleleng. Pemasaran hasil dilakukan dengan menyeragamkan ukuran kebutuhan permintaan pasar, yaitu 8-10 ekor/kg agar harga dapat bersaing.

Strategi pengembangan yang tepat dilakukan di Kabupaten Buleleng adalah mengoptimalkan fungsi Balai Benih Ikan (BBI) Ringdikit menghasilkan benih, menciptakan teknologi budidaya lele dumbo dengan aplikasi tepat guna melalui penyuluh perikanan, memprioritaskan Pokdakan lele dumbo menerima PUMP PB, dan diversifikasi usaha budidaya lele dumbo.

\section{DAFTAR PUSTAKA}

Anonim, 2002. SNI 01-6484.5. Ikan Lele Dumbo Bagian 5 Produksi Kelas Pembesaran di Kolam. Badan Standarisasi Nasional. Jakarta.

Anonim, 2013. Data Statistik Kelautan dan Perikanan: Statistik Perikanan Budidaya Kolam. Direktorat Jenderal Perikanan Budidaya. Jakarta.

Anonim, 2014. Perkembangan Pokdakan Penerima PUMP PB Tahun Anggaran 2011 2014 Kabupaten Buleleng. Buleleng.

Anonim, 2014 . Laporan Kinerja Penyuluh Perikanan Pendamping Program Pengembangan Usaha Perikanan Budidaya (PUMP PB) Tahun 2013 Kabupaten Buleleng. Buleleng.

Ferdian, F., Maulina, I., dan Rosidah., 2012. Analisis Permintaan Ikan Lele Dumbo (Clarias gariepinus) Konsumsi Di Kecamatan Losarang kabupaten Indramayu. Jurnal Perikanan dan Kelautan, 3(4):93-98.

Hermawan, A.T., Iskandar, dan Subhan, U., 2012. Pengaruh Padat tebar Terhadap Kelangsungan Hidup pertumbuhan Lele Dumbo di Kolam Kali Menir Indramayu. Jurnal Perikanan dan Kelautan, 3(3):85-93.

Jaja, Suryani, A., dan Sumatadinata, K., 2013. Usaha Pembesaran dan pemasaran Ikan Lele serta Strategi Pengembangannya di UD Sumber Rezeki Parung, Jawa Barat. Jurnal Magister Profesional Industri Kecil Menengah. 8(1):45-58.

Jorgensen. D. L., 1989. Participant Observation. A Methodology for Human Studies. Sage Publications, Inc. New York.

Khairuman, dan Amri, K., 2002. Budidaya Ikan Lele Dumbo Secara Intensif. Agro Media Pustaka. Jakarta. 
Kirna, I.M., Selamat, I.N., dan Antara, K.L., 2013. IbM Kelompok Pembudidaya Lele di Desa Subuk. Universitas Negeri Ganesha. Singaraja.

Mahyuddin, I., Mahreda, E.S., Mustika, R., dan Febriaty, I., 2014. Analisis Kelayakan Dan Sensitivitas Harga Input Pada Usaha Budidaya Ikan Lele Dalam Kolam Terpal di Kota Banjarbaru Provinsi Kalimantan Selatan. Enviro Scienteae, 10:9-17.

Purwono, J., Sugyaningsih, S., Wibowo, A. E., 2011. Strategi Pengembangan Usaha Pembesaran Ikan Lele Sangkuriang (Clarias gariepinus strain sangkuriang) di Kecamatan Ciampea Kabupaten Bogor. Fakultas Ekonomi dan Manajemen. Institut Pertanian Bogor, Bogor.
Rangkuti, F., 2004. Analisis SWOT Teknik Membedah Kasus Bisnis. Penerbit PT Gramedia Pustaka Utama. Jakarta.

Sudana, S.N., Arga, I.W., dan Suparta, N. 2013. Kelayakan Usaha Budidaya Ikan Lele Dumbo (Clarias gariepinus) dan Pengaruhnya terhadap Tingkat Pendapatan Petani Ikan Lele di Kabupaten Tabanan. Jurnal Manajemen Agribisnis, 1(1):2355-0759.

Septiani, N., Maharani, H.W., Supono, 2014. Pemanfaatan Bioflok Dari Limbah Budidaya Lele Dumbo (Clarias gariepinus) Sebagai Pakan Nila (Oreochromis niloticus). e-JRTBP. 2(2):267-272.

Tajerin, 2008. Efesiensi Teknis Budidaya Pembesaran Lele di Kolam. Jurnal Kajian Ekonomi Negara Berkembang, 12(1):37-48. 